\title{
How Employment Offering Enhances Employees' Intentions to Recommend the Organization as an Employer? The Role of Social Identity and Communications Distinctiveness
}

\author{
Dorothée Hanin ${ }^{1}$, Florence Stinglhamber ${ }^{1} \&$ Nathalie Delobbe ${ }^{2}$ \\ ${ }^{1}$ Université catholique de Louvain, Psychological Sciences Research Institute (IPSY), Belgium \\ ${ }^{2}$ Université catholique de Louvain, Louvain School of Management Research Institute (ILSM), Belgium \\ Correspondence: Dorothée Hanin, Université catholique de Louvain, Psychological Sciences Research Institute \\ (IPSY), Belgium. E-mail: dorothee.hanin@uclouvain.be \\ Received: March 22, 2013 \\ Accepted: April 12, 2013 \\ Online Published: April 23, 2013 \\ doi:10.5430/bmr.v2n2p1 \\ URL: http://dx.doi.org/10.5430/bmr.v2n2p1
}

\begin{abstract}
Despite the interest for employer branding among practitioners, academic research on the topic is still limited. The purpose of the present research was to study the influence of the employment offering diffused by an organization through its communications on its employees' intentions to recommend the organization. More precisely, the present study aimed at examining the effect of the interaction between employment offering and communications distinctiveness on employees' recommendation intentions and the mediating role of social identity, i.e. organizational identification and pride, in this relationship. One-hundred eighty-seven employees of a large international group of the bank industry responded to the questionnaire. Results indicated that, when the employment offering depicts favorable employment conditions and these communications are perceived as distinct from other organizations' communications, employees are more proud of their organization and consequently more willing to recommend it as an employer. By contrast, organizational identification did not mediate the influence of the interaction of employment offering by communications distinctiveness on recommendation intentions. Implications of these findings are discussed.
\end{abstract}

Keywords: Employer branding, Employment offering, Organizational identification, Organizational pride, Recommendation intentions

\section{Introduction}

Globalization, shortage of employees and growing competition for talented workers have motivated companies to increase their visibility as employer in order to attract, recruit, motivate and retain the best employees. Employer branding activities have therefore been considered (Dell \& Ainspan, 2001) as an approach for organizations to communicate to potential and current employees that the organization is a great place to work (e.g., Edwards 2005). More precisely, employer branding "involves promoting, both within and outside the firm, a clear view of what makes a firm different and desirable as an employer" (Backhaus \& Tikoo, 2004, p. 502).

Despite the growing popularity of employer branding among practitioners, academic research on the topic is still limited. The few studies conducted among employees indicated that the perceived benefits associated with employment influence positively employees' organizational attractiveness (Lievens, 2007), their identification (e.g., Lievens, Van Hoye, \& Anseel, 2007), their satisfaction with the job and the organization (e.g., Davies, 2008; Schlager, Bodderas, Maas, \& Cachelin, 2011), their affinity and loyalty with the organization (Davies, 2008) and their intentions to recommend it as an employer (Van Hoye, 2008). Most of this research has studied the impact of employer branding on employees' attitudes, leaving unexplored the mechanisms and the boundary conditions that underlie these relationships. Filling these gaps, the objective of the present study is twofold. First, this research investigates how social identity processes, i.e. organizational identification and pride, explain the relationship between employment offering (i.e., the benefits an organization claims to offer as an employer in its communications) and employees' recommendation intentions. Second, the extent to which the organization's communications are perceived as distinct from other organizations' communications is studied as one specific boundary condition of the impact of employment offering on employees' reactions. 


\subsection{Employment Offering and Recommendation Intentions}

As suggested earlier, employment offering (EO) refers to the benefits the organization claims to offer as an employer in its communication campaigns (Edwards, 2010, p. 6). This EO may depict a unique employment experience by referring to tangible and intangible features that the organization offers to its employees (e.g., training opportunities, challenging jobs) and to elements of the character of the organization itself (e.g., the organizational values and guiding principles). Studying the influence of $\mathrm{EO}$ on employees' intentions to recommend the organization as an employer is interesting due to the potential influence of recommendation intentions on organizations. Recommendation intentions are defined (Van Hoye, 2008) as the extent to which employees intend to recommend their organization as an employer to others. In organizational psychology literature, viability of organizations is linked to employees' willingness to engage in cooperative behaviors (e.g., Podsakoff, Ahearne, \& McKenzie, 1997). Tyler and Blader (2001) consider behavior that engages individuals in non-required behavior to promote the organization's goals as cooperative. Recommendation intentions could then be considered as cooperative intentions and consequently impact favorably the organization. In line with this view, word of mouth, as a recruitment source, is an important determinant of organizational attractiveness (e.g., Van Hoye, 2012) and has a beneficial impact on posthire outcomes such as job satisfaction, performance and likeliness to quit (Breaugh \& Starke, 2000; Zottoli \& Wanous, 2000). These positive consequences may be due to the perception that word of mouth provides realistic and credible information (e.g., Cable \& Turban, 2001). Having ambassadors among their employees might thus be valuable for organizations in order to attract, recruit and motivate potential and current employees. If research has studied the consequences of recommendation intentions, what motivates employees to provide favorable word of mouth has been understudied (Shinnar, Young, \& Meana, 2004). Among the few studies, Van Hoye (2008) has shown that a favorable image of an organization as an employer leads employees to recommend their organization. Consequently, we argue that EO depicting a unique employment experience offered to employees would also influence employees' intentions to recommend their organization.

\subsection{The Role of Social Identity: Organizational Identification and Pride}

Social identity is most commonly defined as "that part of an individual's self-concept which derives from his knowledge of his membership of a social group (or groups) together with the value and emotional significance attached to that membership" (Tajfel, 1978, p. 63). Groups help individuals to define themselves and evaluate their self-worth (Social Identity Theory (SIT): Tajfel \& Turner, 1986). The social identity information that individuals draw from the groups to which they belong is combined with the unique information about themselves to define and evaluate their identity (Tyler \& Blader, 2001). Individuals thus tend to join well-perceived groups because the association with them has positive consequences for the self (Tyler \& Blader, 2001).

In human resources literature, the cognitive component of social identity which refers to 'organizational identification' has been the typical focus of investigation (e.g. Ashforth \& Mael, 1989; Dukerich, Golden, \& Shortell, 2002). Organizational identification refers to the "perception of oneness with or belongingness to an organization, where individual defines him or herself in terms of the organization(s) to which he or she is member" (Mael \& Ashforth, 1992, p. 104). Recently, Blader and Tyler (2009) refined this perspective and asserted, theoretically and empirically, that social identity is best conceptualized by adding an evaluative dimension to the cognitive one. The evaluative dimension which captures the "positive or negative value connotation attached to this group membership" (Ellemers, Kortekaas, \& Ouwerkerk., 1999, p. 372) is composed of two status judgments, i.e. pride and respect (Blader \& Tyler, 2009). Pride corresponds to evaluations of the status of one's group (an intergroup evaluative judgment) and is an assessment of the group's general worth. Respect corresponds to evaluations by people of their status and acceptance within their group (an intragroup evaluative judgment). We only considered pride as the evaluative dimension of social identity in this research because EO draws the attention on the intergroup evaluation, i.e. the unique employment experience an organization claims to offer to differentiate it as an employer from competitors. In line with Blader and Tyler (2009), we thus considered the social identity construct as multidimensional, i.e. encompassing a cognitive (i.e., organizational identification) and an evaluative (i.e., organizational pride) dimension.

According to Ashforth and Johnson (2001), social identity related to organizational membership could be made salient through several communicative ways such as extolling the organization in advertising. The social identity could then be emphasized in EO portraying benefits offered by the organization. Indeed, these benefits could refer to the identity of the organization or provide indications of its status, which may respectively influence organizational identification (e.g., Dukerich et al., 2002) and pride (e.g., Fuller et al., 2006, measured as prestige, Tyler \& Blader (2003)). 
Furthermore, based on group engagement model (Tyler \& Blader, 2003), social identity would act as motivator of cooperative attitudes such as intentions to recommend the organization. Cooperation would result from the motivation to create and maintain a favorable identity (Tyler \& Blader, 2003). The degree to which people engage in supportive attitudes and behaviors toward the organization is determined by the degree to which the organization contributes favorably to the self-image of the individual (Tyler \& Blader, 2001). "It follows, then, that organizational members serve themselves by serving the organization" (Dukerich et al., 2002, p. 511). Empirical evidence supported that organizational identification and pride are associated to cooperation (e.g., Dukerich et al., 2002; Tyler \& Blader, 2002). Specifically, organizational identification and prestige (associated to measure of pride; Tyler \& Blader, 2003) perceived by college alumni were found to predict willingness to advise others to attend the college (Mael \& Ashforth, 1992). Social identity, i.e. organizational identification and pride, could therefore mediate the relationship between $\mathrm{EO}$ and employees' intentions to recommend the organization.

\subsection{The Role of Communications Distinctiveness}

Employer branding activities imply the necessity to differentiate the organization from competitors (e.g., Backhaus \& Tikoo, 2004). As EO is diffused through communication campaigns, we believe that perceived characteristics of these communications, such as their distinctiveness, could be a boundary condition of EO's influence on employees' reactions. SIT supports the view that people need to distinguish themselves from other in social contexts (Tajfel \& Turner, 1986). Distinctiveness "serves to separate "figure from ground", differentiating the group from others (...)" (Ashforth \& Mael, 1989, p. 24). To our knowledge, studies that investigated distinctiveness in this research stream mainly examined the direct effect of the perceived distinctiveness of an organization on employees' attitudes (e.g., Mael \& Ashforth, 1992). Distinctiveness has also been of interest in the literature investigating the relationship between HRM practices and organizational performance. Bowen and Ostroff (2004) suggested that characteristics of HRM system, such as distinctiveness, induce messages about what behaviors are important, expected and rewarded by the organization, which should globally influence employees' attitudes and behaviors and finally impact organizational performance. Although distinctiveness of HRM system has been considered as a predictor of employees' attitudes (e.g., Sanders, Dorenbosch, \& de Reuver, 2008), Riet van't (2011) found that it moderates the relationship between satisfaction with HRM practices and both affective commitment and innovative behavior. Employees are thus more affectively linked to the organization and have more innovative behavior when they are satisfied of their organization' HR practices and these practices are perceived as distinctive.

Similarly, we could assume that communications diffused by an organization to employees to promote itself as an employer are more or less distinctive. In line with Riet van't (2011)'s results, the influence of EO on employees' organizational identification and pride, which in turn impact their intentions to recommend the organization, could then be strengthened if the communications diffused by the organization are perceived as being distinct from other organizations' communications. In line with the views developed above, we hypothesized the following:

H1: The interaction of employment offering by communications distinctiveness on recommendation intentions will be mediated by organizational identification.

$\mathrm{H} 2$ : The interaction of employment offering by communications distinctiveness on recommendation intentions will be mediated by organizational pride.

\section{Method}

\subsection{Sample and Procedure}

The 533 employees surveyed were members of an international group of the bank industry established in Belgium and involved in employer branding practices. The employer branding strategy was developed by the international group and implemented by each country. At the time of the research, the organization surveyed was disseminating information about the favorable job conditions it offers as an employer such as job autonomy or opportunity to use one's skills. These benefits were communicated internally and externally through several media such as internet, intranet and poster campaigns. In agreement with Maxwell and Knox (2009) who suggest taking into account the unique attributes of each organization while studying the perspective of current employees, EO was measured by selecting items that corresponded to the benefits claimed to be offered by the organization. These items were further validated by the organization's HR and marketing departments.

Participants randomly chosen were sent an e-mail explaining the purpose of the study, informing them that their answers will be anonymous, and providing them with a website address to take the questionnaire online. The organization allowed us to ask very few demographical questions within the questionnaire. All in all 187 employees completed the questionnaire. The response rate $(35 \%)$ is within the norm for studies conducted at individual level 
(Baruch \& Holtom, 2008). Of this final sample, $46.5 \%$ were females and $51.9 \%$ were males $(1.6 \%$ missing data). Average age was 42.7 years $(S D=10)$ and average organizational tenure was 17.3 years $(S D=11.9)$.

\subsection{Measures}

Respondents rated their agreement with each statement using a 5-point Likert-type scale ranging from strongly disagree (1) to strongly agree (5).

Employment offering. To assess employees' perceptions of the extent to which their organization's communications depicted favorable benefits, items were selected from several scales (Fuller, Marler, \& Hester, 2006; Jackson \& Mullarkey, 2000; Kristensen \& Borg, 2003; Morgeson \& Humphrey, 2006; Rogelberg, Barnes-Farrell, \& Creamer, 1999) to fit with the EO of the organization, and were adapted to the specific organizational context when needed. Respondents were asked to rate to what extent their organization explicitly portrays in its internal and external communications that it offers jobs including the following job conditions: job autonomy, opportunity to use one's skills, challenging job, opportunity for development, opportunity to take responsibilities, and task diversity.

Communications distinctiveness. To our knowledge, no scale was available in the literature to measure this variable. Based on Brewer's (1991) and Bhattacharya and Sen's (2003) assertions and on the latter authors' proposed items, we developed 4 items to measure the extent to which communications diffused by the organization were distinguishable from other organizations' communications. A sample item is: "I think the communications of [name of the organization] are different from the communications of other organizations".

Organizational pride. Three items adapted from the scale developed by Tyler and Blader (2002) and used by Boezeman and Ellemers (2007) were used to measure organizational pride. A sample item is: "I am proud to be a member of [name of the organization]".

Organizational identification. The 6-item scale of Mael and Ashforth (1992) was used to assess employees' organizational identification. A sample item is: "When I talk about [name of the organization], I usually say 'we' rather than 'they'”.

Recommendation intentions. We used the 3-item scale developed by Van Hoye (2008) to measure employees' willingness to recommend the organization as an employer. A sample item is: "I would recommend [name of the organization] as an employer to others".

Control variables. Age and organizational tenure were the only demographic variables displaying a significant correlation with the dependent variables (i.e., the mediators and the outcome variable). Analyses were done with and without these control variables and results were essentially identical indicating that control variables could be rule out as potential explanations for the findings (Becker, 2005). Only analyses without the control variables are reported here (Becker, 2005).

\section{Results}

\subsection{Discriminant validity}

To assess the distinctiveness of the constructs using Lisrel 8.8 (Jöreskog \& Sörbom, 1993), we compared (Bentler \& Bonnett, 1980) the fit of a five-factor model to more constrained measurement models (four-factor models to one-factor model). Fit indices for measurement models are displayed in Table 1. The hypothesized five-factor model fitted the data well $\left(\chi^{2}(199)=278.62 ; \mathrm{RMSEA}=.05 ; \mathrm{CFI}=.98 ; \mathrm{NNFI}=.98\right)$ and was significantly better than the alternative models. All the individual items loaded reliably on their hypothesized factors with standardized coefficients ranging from .49 to .98 . 
Table 1. Confirmatory Factor Analyses: Fit Indices for Nested Measurement Models

\begin{tabular}{|c|c|c|c|c|c|c|}
\hline Model & df & $\chi^{2}$ & $\Delta \chi^{2}$ & RMSEA & NNFI & CFI \\
\hline 5-factor model & 199 & 278.62 & $\begin{array}{c}--- \\
-1\end{array}$ & .05 & .98 & .98 \\
\hline 4-factor model ( $\mathrm{OP}$ and $\mathrm{OI}=1$ factor) & 203 & 447.83 & $169.21 * * *$ & .08 & .95 & .96 \\
\hline 4-factor model ( $\mathrm{OP}$ and $\mathrm{RI}=1$ factor) & 203 & 688.66 & $410.04 * * *$ & .11 & .87 & .89 \\
\hline 4-factor model (OI and RI = 1 factor $)$ & 203 & 1029.71 & $751.09 * * *$ & .15 & .89 & .90 \\
\hline 4-factor model ( $\mathrm{EO}$ and $\mathrm{CD}=1$ factor) & 203 & 1026.25 & $747.63 * * *$ & .15 & .84 & .86 \\
\hline 4-factor model (EO and $\mathrm{OI}=1$ factor $)$ & 203 & 823.60 & $544.98 * * *$ & .13 & .90 & .91 \\
\hline 4-factor model (EO and $\mathrm{OP}=1$ factor $)$ & 203 & 997.37 & $718.75 * * *$ & .15 & .81 & .84 \\
\hline 4-factor model ( $\mathrm{CD}$ and $\mathrm{OI}=1$ factor) & 203 & 1176.46 & $897.84 * * *$ & .16 & .87 & .89 \\
\hline 3-factor model (OP, OI and RI = 1 factor) & 206 & 861.47 & $582.85 * * *$ & .13 & .85 & .87 \\
\hline 3-factor model ( $\mathrm{EO}$ and $\mathrm{CD}=1$ factor; $\mathrm{OP}$ and $\mathrm{OI}=1$ factor) & 206 & 1193.70 & $915.08 * * *$ & .16 & .81 & .83 \\
\hline 3 -factor model ( $\mathrm{EO}$ and $\mathrm{OP}=1$ factor; $\mathrm{CD}$ and $\mathrm{OI}=1$ factor $)$ & 206 & 2088.84 & $1810.22 * * *$ & .22 & .73 & .76 \\
\hline 3-factor model ( $\mathrm{EO}$ and $\mathrm{OI}=1$ factor, $\mathrm{CD}$ and $\mathrm{OP}=1$ factor $)$ & 206 & 2118.34 & $1839.72 * * *$ & .22 & .74 & .77 \\
\hline 2-factor model (OP, OI and $\mathrm{RI}=1$ factor; $\mathrm{EO}$ and $\mathrm{CD}=1$ factor) & 208 & 1584.96 & $1306.34 * * *$ & .19 & .71 & .74 \\
\hline 2 -factor model (EO, CD and $\mathrm{OP}=1$ factor; $\mathrm{OI}$ and $\mathrm{RI}=1$ factor $)$ & 208 & 2191.87 & $1913.25 * * *$ & .23 & .68 & .71 \\
\hline 2-factor model (EO, CD and $\mathrm{OI}=1$ factor; $\mathrm{OP}$ and $\mathrm{RI}=1$ factor $)$ & 208 & 1987.37 & $1708.75 * * *$ & .21 & .68 & .71 \\
\hline 1-factor model & 209 & 2029.78 & $1751.16 * * *$ & .22 & .66 & .69 \\
\hline
\end{tabular}

Note. $N=187$. The results are described in the text. $\mathrm{EO}=$ employment offering; $\mathrm{CD}=$ communications distinctiveness; $\mathrm{OP}=$ organizational pride; $\mathrm{OI}=$ organizational identification; $\mathrm{RI}=$ recommendation intentions; $d f=$ degrees of freedom; $\Delta \chi^{2}=$ difference in chi-square from the five-factor model; RMSEA = root-mean-square error of approximation; $\mathrm{CFI}=$ comparative fit index; $\mathrm{NNFI}=$ non-normed fit index. $* * * p<.001$.

3.1 Relationships among variables

Table 2 displays descriptive statistics, internal reliabilities and correlations among variables.

Table 2. Means, Standard Deviations, Reliabilities, and Correlations among Variables

\begin{tabular}{llllllllll}
\hline \multicolumn{1}{c}{ Variable } & $M$ & $S D$ & 1 & 2 & 3 & 4 & 5 & 6 & 7 \\
\hline 1. Tenure (in years) & 17.35 & 11.92 & $(-)$ & & & & & & \\
2. Age (in years) & 42.71 & 10 & $.86^{* * *}$ & $(-)$ & & & & & \\
3. Employment offering & 3.68 & .55 & -.04 & .01 & $(.82)$ & & & & \\
4. Communications distinctiveness & 3.18 & .77 & -.11 & -.10 & $.15^{*}$ & $(.92)$ & & & \\
5. Organizational pride & 3.35 & .77 & -.06 & -.04 & $.18^{*}$ & $.40^{* * *}$ & $(.91)$ & & \\
6. Organizational identification & 3.43 & .70 & -.01 & .01 & $.16^{*}$ & $.29^{* * *}$ & $.73^{* * *}$ & $(.84)$ & \\
7. Recommendation intentions & 3.58 & .83 & $-.19^{* *}$ & $-.16^{*}$ & $.31^{* * *}$ & $.42^{* * *}$ & $.57^{* * *}$ & $.40^{* * *}$ & $(.95)$ \\
\hline
\end{tabular}

Note. $N=187$. Cronbach's alphas are provided in parentheses on the diagonal. $* p<.05$. ${ }^{* *} p<.01 .{ }^{* * *} p<.001$.

\subsection{Test of hypotheses}

We tested a structural equation model in which the relationships between EO, communications distinctiveness, and their interaction on recommendation intentions were mediated by organizational identification (Hypothesis 1) and pride (Hypothesis 2). Since we are dealing with latent constructs, we used indicators for the main effects and the interaction term. Following Marsh, Wen and Hau's method (2004) to lessen multicollinearity, the indicators of each latent variable included in the interaction (i.e., the indicators of EO and communications distinctiveness) were centered. We also reduced to four the number of indicators for EO based on preliminary confirmatory factor analyses and using the partial disaggregation method (Bagozzi \& Edwards, 1998). We constructed the first indicator of the latent interaction term by pairing the highest loading indicator of EO with the highest loading indicator of communications distinctiveness. This procedure was followed for each subsequent pair of indicators. Then, we estimated the effects of EO, communications distinctiveness, and their latent product on organizational identification 
and organizational pride, and their effect on recommendation intentions. Table 3 presents fit indices for the hypothesized model and three alternative models. As indicated by the chi- 2 difference test, the fit of Model 3 in which two direct paths were added represents a better depiction of the data. We thus retained this model as the best fitting model.

Table 3. Fit Indices for Nested Structural Models

\begin{tabular}{|c|c|c|c|c|c|c|c|}
\hline Model & $d f$ & $\chi^{2}$ & $\Delta \chi^{2}$ & RMSEA & CFI & NNFI & Model comparison \\
\hline Model 1 (hypothesized) & 240 & 336.45 & & .05 & .98 & .98 & \\
\hline $\begin{array}{l}\text { Model 2: adds path between employment } \\
\text { offering and recommendation intentions }\end{array}$ & 239 & 324.74 & $11.71 * * *$ & .04 & .98 & .98 & Model 1 vs. Model 2 \\
\hline $\begin{array}{l}\text { Model 3: Model } 2 \text { and adds path between } \\
\text { communications distinctiveness and } \\
\text { recommendation intentions }\end{array}$ & 238 & 315.61 & $9.13 * *$ & .04 & .98 & .98 & Model 2 vs. Model 3 \\
\hline $\begin{array}{l}\text { Model 4: Model } 3 \text { and adds path between the } \\
\text { interaction and recommendation intentions }\end{array}$ & 237 & 315.63 & .02 & .04 & .98 & .98 & Model 3 vs. Model 4 \\
\hline
\end{tabular}

Note. $N=187 . d f=$ degrees of freedom; $\Delta \chi^{2}=$ chi-square difference tests between the best fitting model and alternative models; RMSEA $=$ root-mean-square error of approximation; CFI $=$ comparative fit index; NNFI $=$ non-normed fit index. ${ }^{* *} p<.01 . * * * p<.001$.

Standardized parameter estimates for Model 3 are shown in Figure 1. EO, communications distinctiveness and their interaction had a significant positive relationship with organizational pride which, in turn, predicted recommendation intentions. Communications distinctiveness had a significant effect on organizational identification. The effects of EO and the interaction on organizational identification and the effect of organizational identification on recommendation intentions were not significant. Only Hypothesis 2 is thus supported. Finally, EO and communications distinctiveness had also direct effects on recommendation intentions.

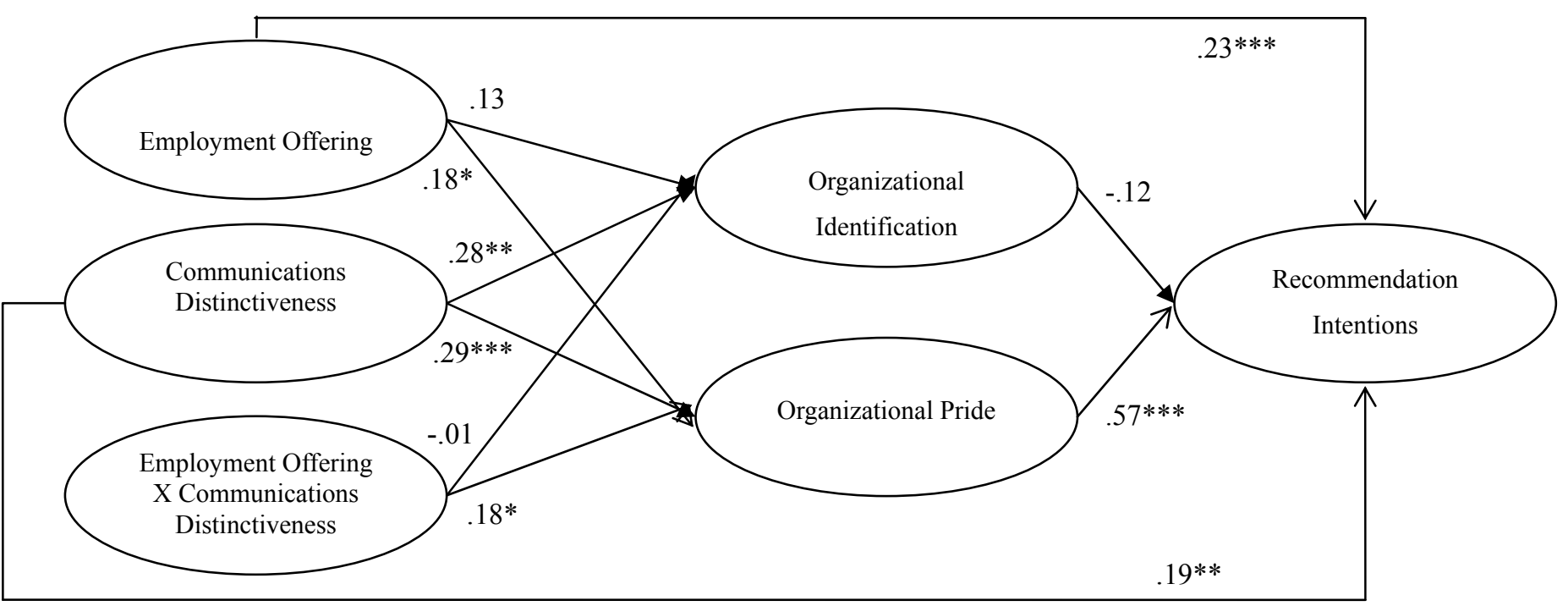

Figure 1. Completely standardized path coefficients for Model 3 (final model).

For the sake of clarity, only structural relationships are shown. ${ }^{*} p<.05 .{ }^{* *} p<.01 . * * * p<.001$.

To further examine the interactive effect of $\mathrm{EO}$ and communications distinctiveness on organizational pride, lines representing the relationship between EO and organizational pride were plotted (Figure 2), at high (1SD above) and low (1SD below) levels of communications distinctiveness. Results of simple slopes tests indicated that the relationship between EO and organizational pride was statistically significant when communications distinctiveness was high $(t(183)=2.87, p<.01)$ and not significant when communications distinctiveness was low $(t(183)=.81$, $p>.05)$. 


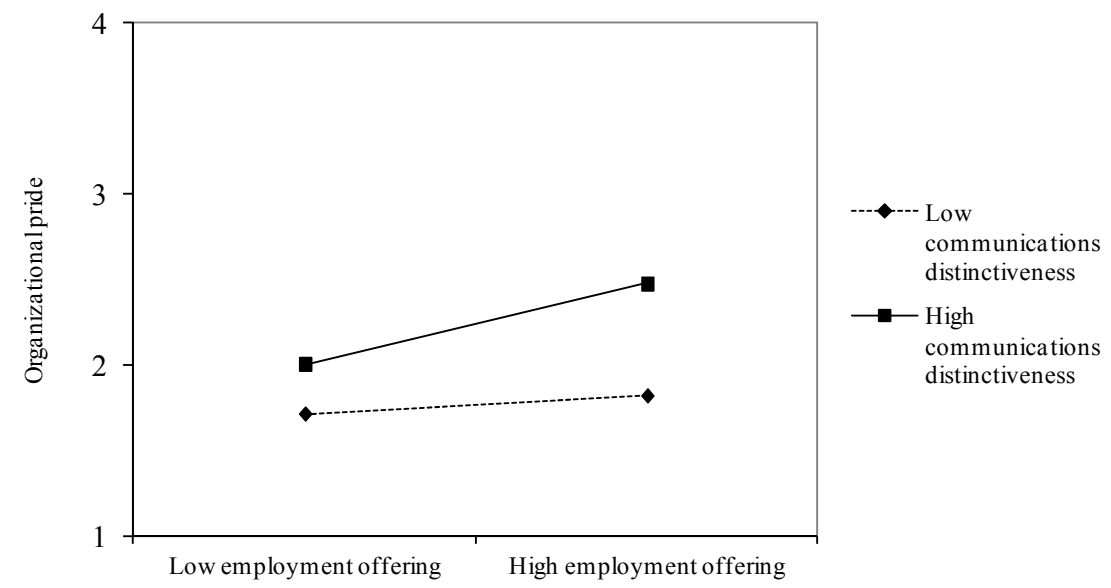

Figure 2. Organizational pride as a function of employment offering at low and high levels of communications distinctiveness

We computed bootstrap analyses to confirm that the interactive effect of EO and communications distinctiveness on organizational pride extends to recommendation intentions (Hayes, 2013; Preacher, Rucker, \& Hayes, 2007). The test of conditional indirect effect indicated that the indirect effect of EO on recommendation intentions via organizational pride was significant when communications distinctiveness was high (indirect effect $=.22$; $\mathrm{BCa} 95 \%$ $\mathrm{CI}=[.07 ; .40]$ ) and not significant when communications distinctiveness was low (indirect effect $=.01 ; \mathrm{BCa} 95 \% \mathrm{CI}$ $=[-.12 ; .16])$. These findings suggested that organizational pride mediated the effect of $\mathrm{EO}$ on recommendation intentions when communications distinctiveness is high. As a whole, these results provide evidence that the interactive influence of $\mathrm{EO}$ and communications distinctiveness on recommendation intentions is totally mediated by organizational pride.

\section{Discussion}

By investigating the mechanisms underlying the relationship between EO and employees' intentions to recommend their organization, the present study adds two main contributions to the research on employer branding. It highlights the mediating process of social identity (i.e., organizational pride) and the role of distinctiveness as a boundary condition of the influence of EO on employees' reactions. Results indicated that the interaction between EO and communications distinctiveness on employees' recommendation intentions is mediated by organizational pride. By contrast, the mediating influence of organizational identification in the relationship between the interaction and employees' intentions to recommend the organization was not supported.

First, our findings suggest that the relationship between EO and organizational pride is influenced by communications distinctiveness. As indicated by the graph of the interaction (Figure 2), employees feel more proud of their organization when the EO diffused by their organization depicts favorable job conditions and these communications are perceived as distinct. Furthermore, this is only when communications are perceived as distinct that EO influences employees' recommendation intentions through organizational pride. In other words, organizational pride mediates the relationship between EO and recommendation intentions only when employees perceive their organization diffuses distinctive communications. These findings suggest that, to elicit feelings of pride among employees and therefore willingness to recommend the organization as an employer, the communications diffused by the organization regarding EO have to be perceived as distinct from other organizations' communications.

The present results might be explained in connection with the identity-based perspective suggested by the group engagement model (Tyler \& Blader, 2003). Through EO, the organization communicates about the job conditions it offers as an employer and consequently gives employees information about the standing and status of the organization. An organization that claims to offer job conditions such as opportunities to develop one's skills or to take responsibilities elicits pride among their employees. Furthermore, in agreement with Riet van't's findings (2011), this feeling is even higher when the organization's communications are perceived as distinct from other organizations because it enhances the perception that the organization is different in comparison to others. 
With regard to the second identity-based mechanism, our findings indicate that the interaction between EO and communications distinctiveness is not significantly associated to organizational identification. These results are not surprising given that organizational identification and pride are close concepts (Blader \& Tyler, 2009) and thus share variance. Taking both variables as potential explaining mechanisms in this study may have decreased the explaining power of organizational identification. The fact that among the two, pride emerges as the significant mediating process may be explained by the nature of these two concepts. By referring to the status of the group and an intergroup judgment (Blader \& Tyler, 2009), pride may elicit more social comparison than organizational identification which refers to the perception of oneness with or belongingness to an organization. In a context of competition, an organization's EO depicting favorable job conditions in communications that are perceived as distinct might influence feelings of pride rather than identification when both concepts are included in the same analysis.

Finally, the present study showed that communications distinctiveness is related to organizational pride and identification. These results are in agreement with Social Identity Theory (Tajfel \& Turner, 1986) supporting the idea that people need to distinguish themselves from others in social contexts. Earlier studies (e.g., Mael \& Ashforth, 1992) demonstrated that alumni of a religious college were likely to experience higher level of identification when they perceived their organization as distinct. The results are also in line with optimal distinctiveness theory (Brewer, 1991) which suggests that people identify with groups balancing the fundamental tension they face, i.e. the tension between their need to belong and their need to be unique.

Over and beyond its contribution to the literature on employer branding, the present research also contributes to the research on recruitment and organizational attractiveness. Indeed, word of mouth has been recently studied as a recruitment source. Several studies showed its influence on applicants' organizational attractiveness (e.g., Van Hoye $\&$ Lievens, 2007). However, research that investigates the determinants of word of mouth and, more specifically, the organizational strategies that would stimulate it is still limited (Shinnar et al., 2004; Van Hoye, 2012). Consequently, by demonstrating that employer branding activities (via EO) stimulate employees' recommendation intentions which, based on results of research on word of mouth, might influence candidates' attitudes towards the organization, this study indirectly contributes to recruitment and organizational attractiveness research.

The present research has several limitations. First, the cross-sectional design did not allow us to make any causal inference regarding the relationships tested. Second, data were self-reported and single-source which raises the possibility that common method variance influenced our findings. However, we believe that self-reported measures were most appropriate for assessing the constructs given that we were interested in employees' perceptions. Furthermore, we assessed common method variance with the Harman one-factor test which suggests that a single-factor solution provided a poor fit with the data (Podsakoff, MacKenzie, Lee, \& Podsakoff, 2003). Additionally, common method variance might lead to an attenuation of the effect of the interaction term (Siemsen, Roth, \& Oliveira, 2010). Finding a significant interaction in our study is therefore strong evidence that an interaction exists. Finally, only one company was surveyed in the present study. Even though it allowed us to focus on this specific organization's EO, that may have attenuated the variance of variables such as EO and, consequently, decreased the probability to find significant relationships. Examining generalizability of these findings in other organizations, industries, and countries would therefore be interesting. This replication is also necessary due to the relatively small sample size that might have reduced the statistical power of the analyses conducted.

In addition to previous suggestions, other research perspectives are presented. First, we apprehended EO by focusing on job conditions. Yet the package of benefits depicted in an EO may also include organizational symbolic traits (e.g., being successful) or values (e.g., Edwards, 2010). Future research should investigate whether the results would generalize with an EO measured with these latter benefits. Second, studies should also examine whether the influence of communications distinctiveness may vary depending on the competitive landscape and the comparison to specific competitors. Indeed, distinctiveness is likely to depend on the competitive landscape (Bhattacharya \& Sen, 2003). With a lot of competitors in the same industry, battle for competent workers might be tighter. In this type of context, the influence of communications distinctiveness on employees' attitudes and behaviors might increase. In addition, because identities are relational and comparative in nature, what is perceived as distinctive can change with the comparison situation (Ashforth, Harrison, \& Corley, 2008). In this research, we compared the distinctiveness of the communications of the studied organization to "other" organizations but we could have also compared it to specific competitors. Depending on the competitor, the influence of communications distinctiveness may vary. 


\section{Practical Implications}

Employer branding has been of great interest for organizations trying to differentiate their image as employer from those of their competitors. Accordingly, it is important for experts in human resources, marketing and communication to understand how employer branding influences employees 'attitudes and behaviors. First, this study indicates that promoting itself as an attractive employer is an efficient way to elicit among employees favorable intentions toward the organization, such as recommendation intentions. EO communications directed at employees are thus a powerful motivator to stimulate favorable reactions from the personnel. Second, experts should keep in mind that in order to elicit feelings of pride and finally intentions to recommend the organization as an employer, the EO communications have to depict favorable employment benefits and to be perceived as distinct. The organization may consult its employees on a regular basis to determine the most valuable benefits to promote. It may also benchmark other organizations' communications in order to effectively distinguish their EO communications from others. Third, the results indicate that job conditions are relevant attributes to diffuse in employer branding campaigns in order to foster employees' attitudes. Finally, this research suggests that employer branding directed at employees also potentially influences candidates. When employees recommend their organization as an employer, they act as ambassadors of their organization disseminating favorable information about it to friends, families, acquaintances and so on. In this direction, the organization should give employees the opportunities to discuss and inform others about their employer through, for instance, campus recruitment or job fair participation, job vacancy diffusion and employee referral. Stimulating employees' favorable recommendations about the organization as an employer is a practice that the organization should not neglect as a potential recruitment channel. Information that is provided by current employees of the organization is perceived as more realistic and credible. As a consequence, candidates develop more realistic expectations regarding the job and organization before entry, with positive consequences for their work attitudes and behaviors in the long run (Buckley et al., 2002; Wanous, Poland, Premack, \& Davis, 1992).

\section{References}

Ashforth, B. E., Harrison, S. H., \& Corley, K. G. (2008). Identification in organizations: An examination of four fundamental questions. Journal of Management, 34, 325-374. http://dx.doi.org/10.1177/0149206308316059

Ashforth, B. E., \& Johnson, S. A. (2001). Which hat to wear: The relative salience of multiple identities in organizational contexts. In M. A. Hogg, \& D. J. Terry (Eds.), Social identity processes in organizational contexts (pp. 31-48). Philadelphia, PA: Psychology Press.

Ashforth, B. E., \& Mael, F. (1989). Social identity theory and the organization. Academy of Management Review, 14, 20-39. http://dx.doi.org/10.2307/258189

Backhaus, K., \& Tikoo, S. (2004). Conceptualizing and researching employer branding. Career Development International, 9, 501-517. http://dx.doi.org/10.1108/13620430410550754

Bagozzi, R. P., \& Edwards, J. R. (1998). A general approach for representing constructs in organizational research. Organizational Research Methods, 1, 45-87. http://dx.doi.org/10.1177/109442819800100104

Baruch, Y., \& Holtom, B. C. (2008). Survey response rate levels and trends in organizational research. Human Relations, 61, 1139-1160. http://dx.doi.org/10.1177/0018726708094863

Becker, T. E. (2005). Potential problems in the statistical control of variables in organizational research: A qualitative analysis with recommendations. Organizational Research Methods, 8, 274-289. http://dx.doi.org/10.1177/1094428105278021

Bentler, P. M., \& Bonnett, D. G. (1980). Significance tests and goodness of fit in the analysis of covariance structures. Psychological Bulletin, 88, 588-606. http://dx.doi.org/10.1037/0033-2909.88.3.588

Bhattacharya, C. B., \& Sen, S. (2003). Consumer-company identification: A framework for understanding consumers' relationships with companies. Journal of Marketing, 67, 76-88.

Blader, S. L., \& Tyler, T. R. (2009). Testing and extending the group engagement model: Linkages between social identity, procedural justice, economic outcomes, and extrarole behavior. Journal of Applied Psychology, 94, 445-464. http://dx.doi.org/10.1037/a0013935

Boezeman, E. J., \& Ellemers, N. (2007). Volunteering for charity: Pride, respect, and the commitment of volunteers. Journal of Applied Psychology, 92, 771-785. http://dx.doi.org/10.1037/0021-9010.92.3.771 
Bowen, D. E., \& Ostroff, C. (2004). Understanding HRM-Firm performance linkages: The role of the "strength" of the HRM system. Academy of Management Review, 29, 203-221. http://dx.doi.org/ 10.5465/AMR.2004.12736076

Breaugh, J. A., \& Starke, M. (2000). Research on employee recruitment: So many studies, so many remaining questions. Journal of Management, 26, 405-434. http://dx.doi.org/ 10.1177/014920630002600303

Brewer, M. B. (1991). The social self: On being the same and different at the same time. Personality and Social Psychology Bulletin, 17, 475-482. http://dx.doi.org/10.1177/0146167291175001

Buckley, M. R., Mobbs, T. A., Mendoza, J. L., Novicevic, M. M., Carraher, S. M., \& Beu, D. S. (2002). Implementing realistic job previews and expectation-lowering procedures: A field experiment. Journal of Vocational Behavior, 61, 263-278. http://dx.doi.org/10.1006/jvbe.2001.1856

Cable, D. M., \& Turban, D. B. (2001). Establishing the dimensions, sources and value of job seekers' employer knowledge during recruitment. In G. R. Ferris (Ed.), Research in Personnel and Human Resources Management (pp. 115-163). New-York: Elsevier Science.

Davies, G. (2008). Employer branding and its influence on managers. European Journal of Marketing, 42, 667-681. http://dx.doi.org/10.1108/03090560810862570

Dell, D., \& Ainspan, N. (2001). Engaging Employees through Your Brand. Conference Board Report No. R-1288-01-RR, April, Conference Board, Washington, DC.

Dukerich, J. M., Golden, B. R., \& Shortell, S. M. (2002). Beauty is in the eye of the beholder: The impact of organizational identification, identity, and image on the cooperative behaviors of physicians. Administrative Science Quarterly, 47, 507-533. http://dx.doi.org/10.2307/3094849

Edwards, M. R. (2005). Employer and employee branding: HR or PR? In S. Bach (Ed.), Human Resource Management: Personnel Management in Transition (pp. 266-286). Oxford: Blackwell.

Edwards, M. R. (2010). An integrative review of employer branding and OB theory. Personnel Review, 39, 5-23. http://dx.doi.org/10.1108/00483481011012809

Ellemers, N., Kortekaas, P., \& Ouwerkerk, J. W. (1999). Self-categorisation, commitment to the group and group self-esteem as related but distinct aspects of social identity. European Journal of Social Psychology, 29, 371-389. http://dx.doi.org/10.1002/(SICI)1099-0992(199903/05)29:2/3<371::AID-EJSP932>3.0.CO;2-U

Fuller, J. B., Hester, K., Barnett, T., Frey, L., Relyea, C., \& Beu, D. (2006). Perceived external prestige and internal respect: New insights into the organizational identification process. Human Relations, 59, 815-846. http://dx.doi.org/10.1177/0018726706067148

Fuller, J. B., Marler, L. E., \& Hester, K. (2006). Promoting felt responsibility for constructive change and proactive behavior: Exploring aspects of an elaborated model of work design. Journal of Organizational Behavior, 27, 1089-1120. http://dx.doi.org/10.1002/job.408

Hayes, A. F. (2013). Mediation, moderation, and conditional process analysis. New York, NY: The Guilford Press.

Jackson, P., \& Mullarkey, S. (2000). Lean production teams and health in garment manufacture. Journal of Occupational Health Psychology, 5, 231-245. http://dx.doi.org/10.1037//1076-8998.5.2.231

Jöreskog, K. G., \& Sörbom, D. (1993). LISREL 8: User's reference guide. Chicago, IL: Scientific Software International.

Kristensen, T. S., \& Borg, V. (2003), "The Copenhagen Psychosocial Questionnaire (COPSOQ): A questionnaire on psychosocial working conditions, health and well-being in three versions [internet]", The National Institute of Occupational Health, Denmark. Retrieved http://www.arbejdsmiljoforskning.dk/ /media/Spoergeskemaer/copsoq/english-copsoq-2-ed-2003-pdf.pdf.

Lievens, F. (2007). Employer branding in the Belgian army: The importance of instrumental and symbolic beliefs for potential applicants, actual applicants, and military employees. Human Resource Management, 46, 51-69. http://dx.doi.org/10.1002/hrm.20145

Lievens, F., Van Hoye, G., \& Anseel, F. (2007). Organizational identity and employer image: Towards a unifying framework. British Journal of Management, 18, 45-59. http://dx.doi.org/10.1111/j.1467-8551.2007.00525.x 
Mael, F., \& Ashforth, B. E. (1992). Alumni and their Alma-Mater - A partial test of the reformulated model of organizational identification. Journal of Organizational Behavior, 13, 103-123. http://dx.doi.org/10.1002/job.4030130202

Marsh, H. W., Wen, Z. L., \& Hau, K. T. (2004). Structural equation models of latent interactions: Evaluation of alternative estimation strategies and indicator construction. Psychological Methods, 9, 275-300. http://dx.doi.org/ 10.1037/1082-989x.9.3.275

Maxwell, R., \& Knox, S. (2009). Motivating employees to "live the brand": A comparative case study of employer brand attractiveness within the firm. Journal of Marketing Management, 25, 893-907. http://dx.doi.org/ $10.1362 / 026725709 X 479282$

Morgeson, F. P., \& Humphrey, S. E. (2006). The Work design questionnaire (WDQ): Developing and validating a comprehensive measure for assessing job design and the nature of work. Journal of Applied Psychology, 91, 1321-1339. http://dx.doi.org/10.1037/0021-9010.91.6.1321

Podsakoff, P. M., Ahearne, M., \& MacKenzie, S. B. (1997). Organizational citizenship behavior and the quantity and quality of work group performance. Journal of Applied Psychology, 82, 262-270. http://dx.doi.org/10.1037/0021-9010.88.5.879

Podsakoff, P. M., MacKenzie, S. B., Lee, J. Y., \& Podsakoff, N. P. (2003). Common method biases in behavioral research: A critical review of the literature and recommended remedies. Journal of Applied Psychology, 88, 879-903. http://dx.doi.org/10.1037/0021-9010.88.5.879

Preacher, K. J., Rucker, D. D., \& Hayes, A. F. (2007). Addressing moderated mediation hypotheses: Theory, methods, and prescriptions. Multivariate Behavioral Research, 42, 185-227. http://dx.doi.org/10.1080/00273170701341316

Riet van 't, S. (2011), Focusing on employees' perception of HRM; shed some light into the black box...: HRM satisfaction and distinctiveness considered" (Master's thesis). Retrieved from: http://essay.utwente.nl/61052/

Rogelberg, S. G., Barnes-Farrell, J. L., \& Creamer, V. (1999). Customer service behavior: The interaction of service predisposition and job characteristics. Journal of Business and Psychology, 13, 421-435.

Sanders, K., Dorenbosch, L., \& de Reuver, R. (2008). The impact of individual and shared employee perceptions of HRM on affective commitment. Personnel Review, 37, 412-425. http://dx.doi.org/10.1108/00483480810877589

Schlager, T., Bodderas, M., Maas, P., \& Cachelin, J. L. (2011). The influence of the employer brand on employee attitudes relevant for service branding: An empirical investigation. Journal of Services Marketing, 25, 497-508. http://dx.doi.org/10.1108/08876041111173624

Shinnar, R. S., Young, C. A., \& Meana, M. (2004). The motivations for and outcomes of employee referrals. Journal of Business and Psychology, 19, 271-283.

Siemsen, E., Roth, A., \& Oliveira, P. (2010). Common method bias in regression models with linear, quadratic, and interaction effects. Organizational Research Methods, 13, 456-476. http://dx.doi.org/10.1177/1094428109351241

Tajfel, H. (1978). Social categorization, social identity and social comparison. In H. Tajfel (Ed.), Differentiation between social groups: Studies in the social psychology of intergroup relations (pp. 61-76). London: Academic press.

Tajfel, H., \& Turner, J. C. (1986). The social identity theory of intergroup behavior. In S. Worchel \& W. G. Austin (Eds.), Psychology of intergroup relations (2nd ed., pp. 7-24). Chicago: Nelson-Hall.

Tyler, T. R., \& Blader, S. L. (2001). Identity and cooperative behavior in groups. Group Processes \& Intergroup Relations, 4, 207-226. http://dx.doi.org/10.1177/1368430201004003003

Tyler, T. R., \& Blader, S. L. (2002). Autonomous vs. comparative status: Must we be better than others to feel good about ourselves? Organizational Behavior and Human Decision Processes, 89, 813-838. http://dx.doi.org/10.1177/1368430201004003003

Tyler, T. R., \& Blader, S. L. (2003). The group engagement model: Procedural justice, social identity, and cooperative behavior. Personality and Social Psychology Review, 7, 349-361. http://dx.doi.org/10.1207/S15327957PSPR0704_07 
Van Hoye, G. (2008). Nursing recruitment: Relationship between perceived employer image and nursing employees' $\begin{array}{lllll}\text { recommendations. Journal of } & \text { Advanced }\end{array}$ http://dx.doi.org/10.1111/j.1365-2648.2008.04710.x

Van Hoye, G. (2012). Recruitment sources and organizational attraction: A field study of Belgian nurses. European Journal of Work and Organizational Psychology, 21, 376-391. http://dx.doi.org/10.1080/1359432X.2011.573146

Van Hoye, G., \& Lievens, F. (2007). Social influences on organizational attractiveness: Investigating if and when word-of-mouth matters. Journal of Applied Social Psychology, 37, 2024-2047. http://dx.doi.org/10.1111/j.1559-1816.2007.00249.x

Wanous, J. P., Poland, T. D., Premack, S. L., \& Davis, K. S. (1992). The effects of met expectations on newcomer attitudes and behaviors: A review and meta-analysis. Journal of Applied Psychology, 77, 288-297. http:// dx.doi.org/10.1037/0021-9010.77.3.288

Zottoli, M. A., \& Wanous, J. P. (2000). Recruitment source research: Current status and future directions. Human Resource Management Review, 10, 353-382. http://dx.doi.org/10.1016/S1053-4822(00)00032-2 